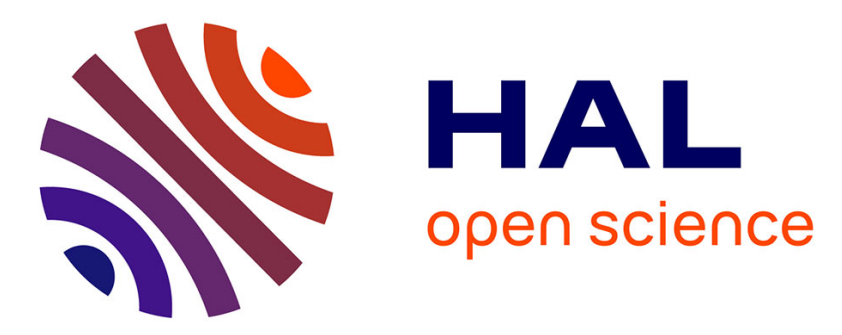

\title{
"The Eyes and Ears of the Agricultural Markets": A History of Information in Interwar Agricultural Economics
}

Thomas Delcey, Guillaume Noblet

\section{- To cite this version:}

Thomas Delcey, Guillaume Noblet. "The Eyes and Ears of the Agricultural Markets": A History of Information in Interwar Agricultural Economics. 2021. hal-03227973

\author{
HAL Id: hal-03227973 \\ https://hal.science/hal-03227973 \\ Preprint submitted on 17 May 2021
}

HAL is a multi-disciplinary open access archive for the deposit and dissemination of scientific research documents, whether they are published or not. The documents may come from teaching and research institutions in France or abroad, or from public or private research centers.
L'archive ouverte pluridisciplinaire HAL, est destinée au dépôt et à la diffusion de documents scientifiques de niveau recherche, publiés ou non, émanant des établissements d'enseignement et de recherche français ou étrangers, des laboratoires publics ou privés. 


\title{
"The Eyes and Ears of the Agricultural Markets"*
}

\author{
A History of Information in Interwar Agricultural Economics
}

\author{
Delcey, Thomas ${ }^{\dagger} \quad$ Noblet, Guillaume ${ }^{\ddagger}$
}

May 2021

\begin{abstract}
This article offers a historical analysis of the contributions of U.S. interwar agricultural economics to the economics of information. Concerned with improving the circulation of information on agricultural markets, agricultural economists analyzed the relationship between agents' information and the behavior of prices on agricultural commodity exchanges, thus anticipating modern debates on informational efficiency. We show that these debates were part of a more general context of agricultural market reform led by the U.S. administration to improve the production and diffusion of economic information. We argue that such reforms were a prerequisite for theoretical discussions on information, and established institutional tools that are still active today, such as the USDA market news service.
\end{abstract}

In 2015, the USDA celebrated the centenary of its market news service (Alonzo 2017). The market news service chiefly aims to provide market participants with free and unbiased information on prices on the agricultural commodities market. USDA's first radio report in 1915 broadcast to growers and shippers the prices of strawberries, tomatoes, cantaloupes, peaches, and pears. Today, the USDA market news service still provides

${ }^{*}$ The authorship of this expression must be attributed to Nils A. Olsen, chief of the Bureau of Agricultural Economics in the USDA in 1933.

†Corresponding author: thomas.delcey@univ-paris1.fr, Université Paris 1 Panthéon-Sorbonne, Centre d'Economie de la Sorbonne, REHPERE

†Indépendant, REHPERE 
prices and other relevant information on U.S. agricultural products. The establishment of the market news service was part of a larger USDA program during the interwar period to improve the production and diffusion of agricultural market information. This article relates the role that agricultural economists played in this program, and in particular their views on the concept of information.

In the history of economics, information is mainly perceived as a concept that emerged from the socialist calculation debate and that was subsequently developed in a more formal framework through the influences of other sub-disciplines such as cybernetics and mathematics (Mirowski and Nik-Khah 2017). Little has been said about prewar theories of information in economics. Yet, it has already been acknowledged that early U.S. agricultural economists viewed information as a key issue for improving the efficiency of agricultural markets. For instance, agricultural economists were early advocates of market transparency, which eventually lead to the first regulation of futures exchanges in the 1920s (Berdell and Choi 2018; Saleuddin 2018). Moreover, the agricultural economist Holbrook Working formulated an early (and personal) version of the efficient market hypothesis, which states that asset prices fully integrate all available information (Jovanovic 2008). . $^{1}$

Apart from Working, no other significant analytical contributions to information theory from contemporary agricultural economists have been acknowledged by historians. While not considered as contributing to economic theory, this article shows that interwar agricultural economists were actively concerned with the informedness of market participants. In the 1920s, in the context of the expansion of the USDA, economists were at the forefront of agricultural market reforms that sought to improve the production and circulation of information (leading to the creation of the still-existing market news service). We investigate how, through such reforms, agricultural economists built and shared a set of knowledge on information and how it influenced the later theoretical contributions of Working.

\footnotetext{
${ }^{1}$ The writings of Working and their influence on modern financial economists have already been noticed. See for instance the relationship between Working and MIT financial economists (Delcey 2019 . Jovanovic 2008).
} 
We argue that agricultural economists' knowledge on information was twofold. First, they believed that improving the informedness of market participants was the best way to achieve proper functioning of agricultural markets. While allowing farmers to get better prices, economists' reforms also aimed to direct the efficient allocation of resources. Second, they thought that market participants were mostly ill-informed and thus that the State might help to produce and disseminate economic information. Rather than interpreting Working as an isolated pioneer of financial economics, this article intends to explain the collective dynamics preceding and surrounding his contributions. We essentially focus on the emergence of economic institutions and the debates on information within the USDA between 1862 and the early 1930s, with an emphasis on the 1920s.

It is important to note that interwar agricultural economics was essentially publicfunded. The boundaries between academia and expertise were not drawn clearly: many agricultural economists were civil servants within the USDA. They not only published scientific writings; they also built institutional devices to reform and improve the agricultural economy. Consequently, a large of part our work focuses on the role they played within this administration. The primary sources we use are three annual USDA public reports - the USDA yearbook, the report of the Chief of the Bureau of Agricultural Economics, and the report of the Chief of the Grain Futures Administration 2 - and published writings from economists affiliated with the USDA.

This article contributes firstly to the history of information in economics. We exhibit how information was central in economists' debates and economic policies long before the post-war era. This result remains consistent with other findings showing that at the end of the $19^{\text {th }}$ century, it was already "popular knowledge" among investors that asset prices reflect information (Preda 2004). This calls for further investigation of early economic knowledge on the informational role of markets. It also contributes to the history of agricultural economics by shedding light on the role played by some agricultural economists in the establishment of both economic administrations and the market news service. Finally, we contribute to the history of financial economics by enriching our

\footnotetext{
${ }^{2}$ The bibliographic references to these archives in the body of the text are respectively USDA, BAE and GFA.
} 
understanding of Working's contributions to financial theory.

The paper is structured as follows. Section 1 relates how USDA's interest in information arose from political concerns, and from the converging interests of policymakers, farmers, and businesspeople. The USDA launched a large economic research agenda in order to meet this demand. Section 2 shows the central role of agricultural economists in this research agenda. We focus on the establishment in the early 1920s of economic federal administrations, namely the Bureau of Agricultural Economics and the Grain Futures Administration. Both institutions sought to improve the production and diffusion of information. Sections 3 and 4 explain the institutional devices by which agricultural economists gathered and disseminated information to market participants. It emphasizes how agricultural economists viewed the government as the producer and distributor of impartial and unbiased agricultural economic information. Section 3 explains how the information was produced and edited. Section 4 focuses on the establishment and functioning of the market news service. Section 5 investigates, in particular, the kind of efficient market hypothesis that Holbrook Working formulated. We relate how his view contrasted with - but was intimately related to - the USDA research agenda.

\section{The growing demand for economic information of market participants (1862-1926)}

Historically, providing reliable "information" to farmers was a core feature of USDA's agenda. When President Lincoln established the USDA in 1862, he explicitly formulated the need for U.S. agriculture to learn from science to achieve this goal. A year later, in 1863, the USDA established the first monthly reports on crops. Its original mandate enjoined to promote "the general welfare of rural Americans" by "diffus[ing] among the people of the United States useful information on subjects connected with agriculture in the most general and comprehensive sense of the word"(Wik 1988, p. 177). The Colleges of Agriculture or "land-grant colleges" - were established the same year (Morrill Act), and experimental stations were funded in these colleges in 1887 (Hatch Act). State colleges 
produced research on every topic related to agriculture: farm management, biology, and chemistry. Due to political reluctance, this initial impetus for the use of science in agricultural policy did not materialize until the late 1800s.3 According to Carpenter (2001, p. 179): "by 1890 the Department of Agriculture was the strongest voice for scientific policymaking in the federal government, if not the entire nation".

In the late $19^{\text {th }}$ century, the U.S. agricultural sector was in crisis, afflicted by low prices, overproduction, and monopolies. As farmers and politicians understood it, prices remained too low, and farmers could neither live decently nor integrate the vibrant rise of the consumer society. Moreover, farmers believed that low prices were caused by traders (Santos 2008). They considered that the price of their supply was settled on agricultural exchanges, e.g, the Chicago Board of Trade, and that they remained misinformed about market trends and their underpinnings (Wik 1988, p. 178). From the 1880s, farmers progressively gathered and organized themselves at the national and local level. 45 Farmers societies started to disseminate practical information to farmers in an effort to spread scientific knowledge. They believed that education-courses, test plots, demonstration of new methods, boys' and girls' clubs, etc.-and information were the key to solve the problem of low prices (Fite 1971; Scott 1971). Some farmers asked for any information that would improve their knowledge on any subject related to agriculture, from weather and fertilizers to farm management. The need to improve farmers' information on market conditions was grasped, if not encouraged, by politicians. For instance, in 1889, Secretary Jeremiah M. Rusk already reported that thousands "of letters of inquiry for information" were sent to the USDA "from all sections of the country, from all classes and conditions" (quoted in Harding 1947, p. 330).

From the 1910s, a third party entered the ongoing equation: the business community. Facing a growing need to forecast prices, businesspeople became strongly interested in

\footnotetext{
${ }^{3}$ Resistance to the introduction of an applied scientific research program (especially biology and chemistry) came from both the farmers' societies and some Republican congressmen. In these first two decades, the USDA's so-called applied research was limited to the publication of price and quantity bulletins and the distribution of seeds (Carpenter 2001).

${ }^{4}$ For example, the Grange - a farmers' union, based in the North-East - promoted popular education and made social demands against monopolies, especially transportation monopolies. In 1875, it had 800,000 members. The Grange was no stranger to the lobbying that led to the Smith Lever Act of 1914 and the establishment of the Farm Credit System.
} 
market information, particularly in agricultural statistics like price series (Stapleford 2017). Hence, during the 1920s, a convergence occurred between businesspeople's and farmers' interest in receiving market information.

The early agricultural economists - e.g., Henry C. Taylor, George F. Warren, William J. Spillman, and Thomas N. Carver-were working in land-grant colleges and experiment stations.5 Many agricultural economists were trained as institutionalists or close to institutionalism (e.g., Taylor was a student of John R. Commons at the University of Wisconsin). They also shared Victorian-American values, including the belief that education was a tool for the enlightenment and moral improvement of the people (McDean 1984).

The legislative apparatus developed economic research that would meet these interests in information and education. The institutionalization of economics within the USDA took decades. However, several department officials were already meeting in the American Farm Management Association and in the USDA's Rural Economics Club - a group of about 50 USDA researchers (Carpenter 2001). It reached a peak under Secretary Henry C. Wallace with the establishment of the Grain Futures Administration (1921) and the Bureau of Agricultural Economics (BAE, 1922). During the same decades, Agricultural Experiment Stations pursued economic research that was officially recognized by the Purnell Act (1926). According to Secretary Henry A. Wallace, the establishment of the BAE allowed farmers to better adapt to market conditions and to direct efficient production:

It is now possible to make a comprehensive study of economic questions involved in production, marketing, and distribution of farm products, following every step of these processes. This is necessary to secure for farmers the information needed to put American agriculture upon a permanently productive and profitable basis. (USDA 1923, p. 17)

\footnotetext{
${ }^{5}$ The main land-grant colleges they worked in were Massachusetts, Iowa, Nebraska, California, Michigan, Wisconsin, New York, and Minnesota. Most of those "pioneers" of agricultural economics-some of whom were considered rural social scientists - were born and raised on Midwest farms. See McDean (1983) for more details.
} 
The growing demand for information led to the development of publicly-funded agricultural economic research. The next section describes how, starting in the 1920s, agricultural economists seized upon the issue of information.

\section{The establishment of the Bureau of Agricultural Economics and the Grain Futures Administration}

The increasing importance of economics in agricultural policy lied in the establishment of two federal administrations within the USDA in 1921-22: the Bureau of Agricultural Economics and its Graduate School, and the Grain Futures Administration (GFA).6 in 1982.

The BAE eventually gathered all aspects of the integration of economics in the USDA. It brought together a large group of economists or economic-oriented scholars (Fox 1986). It mainly hired PhD agricultural economists from land-grant colleges such as the University of Wisconsin, the University of Minnesota, and Cornell University (National Archives 1995). Imbued with U.S. institutionalism, the agricultural economists of the interwar period were characterized by a pragmatic conception of science, a strong empirical tradition, and a clear interest in economic policy (Mehrling 1997; Mirowski 1987). Wisconsin University was both one of the main centers of agricultural economics and a stronghold of American institutionalists. Leading agricultural economists like Taylor, Ezekiel, Tugwell or H. Working had been economic advisers for US secretaries of agriculture (Rutherford 2001, p. 182; Berdell and Choi 2018, p. 550).

In 1922, under the impetus of Secretary Wallace and Taylor-its first director - the BAE was established by merging three pre-existing institutions (Warren 1932; Taylor 1940; Chancellier 2014): the Bureau of Markets (1917-21), the Office of Farm Management and Farm Economics (1920-22) and the Bureau of Crop Estimates (1914-22). The

\footnotetext{
${ }^{6}$ The BAE lasted until 1953. After being re-dispatched to other bureaus, it became the Economic Research Service in 1961. The GFA became the Commodity Exchange Administration in 1936, and eventually the Commodity Futures Trading Commission
} 
Bureau of Markets, whose activity was integrated into the BAE, had already been commissioned by Congress to "get market information to farmers more rapidly". The BAE then functioned as a research agency at the intersection of economics, statistics, and planning. Planning was reinforced with the New Deal and the Agricultural Adjustment Act (AAA) in 1933; yet, economists from the BAE had already advocated for planning years before (see the seminal work of Kirkendall 1966). The mandate of the Bureau explicitly mentioned the dissemination of economic information:

Conducted studies and disseminated information relating to agricultural production, crop estimates, marketing, finance, labor, and other agricultural problems. Served as the central planning agency for economic and statistical research in the Department of Agriculture. (National Archives 1995).

Moreover, the Graduate School of the USDA 7 was established in 1921, with the objective to meet the rising demand for statistical and economic expertise. The School mainly trained USDA civil servants. It did not offer degrees but provided courses in economics and statistics for many university degrees..$^{8}$ The Graduate School invited prominent statisticians such as Ronald Fisher or Jerzy Neyman. Many well-known figures taught economic courses, for instance on land economics or price analysis. Notable teachers included Henry C. Taylor and economists who worked on early econometrics such as Mordecai Ezekiel, E. J. Working, Holbrook Working, Howard Tolley, W. J. Spillman, Louis Bean, and Frederick Waugh (McDean 1984; Morgan 1991; Rutherford 2011).

The second federal agency, the Grain Futures Administration (GFA), was established in 1921 (Grain Futures Act, 1922) as a response to farmers' demands for the regulation of futures markets. The U.S. futures exchanges had been controversial for years, although no attempt at regulation had been made before the end of World War 1 (Santos 2008). Since some of the public viewed the futures markets as gambling, causing prices to rise artificially at the expense of farmers, the GFA was tasked with preventing the manipulation of prices leading to excessive fluctuations:

\footnotetext{
${ }^{7}$ For the history of the Graduate School, see Rutherford (2011).

${ }^{8}$ Such as Columbia, Cornell, Yale, Harvard, Johns Hopkins, Chicago, California, Michigan, New York, Illinois, and Iowa (ibid., p. 423).
} 
The transactions and prices of grain on such boards of trade are susceptible to speculation, manipulation, and control, and sudden or unreasonable fluctuations in the prices thereof frequently occur as a result of such speculation, manipulation, or control, which are detrimental to the producer or the consumer ... and render regulation imperative for the protection of such commerce and the national public interest therein. (Grain Futures Act, 1922, in Berdell and Choi 2018, p. 541)

However, the GFA remained a small agency within the USDA compared with the BAE. In terms of budget, the GFA's regular expenditure was $\$ 100,000-200,000$ in the 1920s and the 1930s, compared with the BAE's expenditure of millions of dollars (see USDA's yearbooks, e.g. USDA 1926, p. 98). Nonetheless, it was one of the earliest attempts to study and regulate modern exchanges. In the 1920s, the GFA did not have any real coercive power on futures exchanges and thus focused mostly on "information gathering" about futures markets (Saleuddin 2018, p. 162). Economists within the GFA mainly sought to prevent "the dissemination of false or misleading market information" (GFA 1924, p. 3). They pursued this objective, with the assistance of the other USDA agencies and notably the BAE, in order to verify the accuracy of published statements on market conditions (ibid., p. 26). The GFA tried to measure the influence of illinformed trading activities on spot and futures price movements, driving them away from agricultural fundamentals (Berdell and Choi 2018, p. 540). Hence, if the GFA was mainly concerned by market regulation, it was also a pioneer research institution on financial activities, collecting and analyzing data on speculative activities in agricultural markets (see section 3).

The mandates of the BAE and the GFA centered around the production and diffusion of economic information. BAE and GFA economists obviously believed that producing information and making it available would improve the efficiency of the agricultural economy. Within these administrations, the nature of daily work was a hybrid of economic research and policymaking. They were particularly concerned with improving farmers' economic conditions. A large part of their effort was neither theoretical nor empirical, 
but practical. Rather than analyzing agricultural markets, they wanted to reform them by producing and editing information for market participants.

\section{Producing and editing information}

The USDA was an important and innovative actor in the development of U.S. statistics in the 1920s and the 1930s, in terms of both data production and statistical analysis (Didier 2009; Biddle 1999). A large part of this statistical work relied on market information. It targeted market participants so that they could better adapt to economic conditions. Its first director, Taylor, argued that the BAE's purpose was to "serve as a sort of barometer of the agricultural industry" (BAE 1924, p. 2).9 $9^{9}$ The relationship between market participants and agricultural economists was not a unilateral relationship in which the uninformed agents learned from the expert economists. To increase not only market participants' information but also its control of the agricultural economy, the USDA needed to improve its knowledge (Saleuddin 2018; Didier 2009). In fact, the State and the economists knew little more than the market participants about the economy of the agricultural sector. For futures markets, simple information like price levels or trading volumes did not exist or were kept private by traders (Saleuddin 2018, p. 281). Before any dissemination of information, the work of the USDA's economists was twofold. First, they collected data to produce information on the agricultural economy. Second, they edited that information for the practical use of market participants.

The USDA collected information on markets and also on a variety of other subjects as long as it could help market participants. For that purpose, they promoted a plurality of empirical methods like cost accounting, surveys, and geographical methods. In particular, from the 1920s on, they promoted experimental work. Experimental stations and the BAE worked on joint experiments in rural sociology, agricultural engineering, soil and fertilizers, animal and dairy husbandry, and so on. By 1930, 7,000 experimental projects were active in the US, of which one eighth were devoted to agricultural economics

\footnotetext{
${ }^{9}$ At the same time, the development of statistics was also fostered by the research on business cycles, like the Harvard Barometer (Morgan, 1991).
} 
(USDA 1930). Besides setting up new protocols (e.g., Call, Green, and Swanson 1925), agricultural economists notably discussed statistical theory such as significance tests using samples and field experiments (Grimes 1929, Wilson 1929; Elliott 1929, Fisher 1925). Within the Bureau of Crop Estimates and then the BAE, early attempts at random sampling to conduct surveys were made; likewise, surveys were used for price forecasting (Didier 2009).

Historically, the USDA already collected data, mostly on annual production and monthly prices (e.g. USDA 1907, p. 542). From the 1910s, county agents were in charge of collecting data locally for the Federal State. In particular, they interviewed farmers in order to fill in forms with price data that were sent to the Bureau of Statistics (Didier 2009, pp. 27-36). From 1913, the Bureau of Statistics was dispatched to other Bureaus (USDA 1914, p. 14). The Bureau of Markets, and then from 1921 the BAE, became in charge of collecting statistics on the agricultural economy. Statistics on prices and supplies progressively improved, mainly by increasing the range of goods and the periodicity of price data. The BAE also provided data analysis, such as forecasts, which the $\mathrm{Bu}-$ reau of Crop Estimates (1914-1922) had previously provided. Alongside this statistical work, the BAE endeavored to improve the grades and the standardization of agricultural products (USDA $1923 / 24-1934 / 35$, p. 7). This issue, very important in the department during the whole decade, was viewed as a means to improve information coordination between market participants (Lenfant 2017, p. 17).

Some agricultural economists also used records from private actors, dealers, or specialized newspapers. For instance, in one of his first publications, Working collected data on the historical prices of potatoes thanks to newspapers and private dealers (Working 1922 , pp. 11-12). Moreover, before the 1920s, most market participants, academics, and policy-makers knew little about agricultural exchanges, especially futures exchanges. As a consequence, one of the main tasks of the GFA in the 1920s was to build a legal environment that would enforce more transparency on futures exchanges, like the Chicago Board of Trade (Saleuddin 2018, p. 165). The Grain Futures Act (1922) obliged traders to report daily or weekly information such as their net position and the number of con- 
tracts traded on the period, and the quantity of goods received or delivered (Saleuddin 2018, p. 165). To achieve such transparency, the GFA collected crucial data on futures exchanges that were necessary to understand and analyze these markets. In 1923, the GFA delivered their first studies about futures markets, on price movements, volumes exchanged, and the features of economic agents engaged in futures trading (GFA 1924).

While they sought to help all market participants, the work of BAE's economists mainly targeted farmers. The BAE handed down several types of information to them like historical prices, forecasts, factors influencing prices, general agricultural economic research, and farm management advice (Lininger 1929). Economic information took many forms: exhibits, posters, charts, models, films, addresses, radio talks, correspondence, and press releases. These forms needed strong editorial work beforehand and the editing of such information was at the heart of many discussions about the expertise of agricultural economists: should data be sent raw or should the information be sorted by economists to facilitate their reading? Should economists only provide data or should they interpret them and suggest forecasts? Some articles from agricultural economists directly discussed the editing of information during the 1920s (Lininger 1929; Hart 1929; Williams 1929; Cooper 1929, Estabrook 1923). Professor Lininger, an agricultural economist from Pennsylvania State College, summarized the issue as follows:

From the great mass of information available, it is possible to glean something like answers to the four abiding questions of the farmer: "What, when, where, and how shall I sell, in order to obtain the highest net price?" In other words, what do all these statistics and expert calculations mean to the farmer himself. (Lininger 1929, p. 348)

Estabrook (1923) - former chief of the Bureau of Crop Estimates and associate chief of the BAE - stated that farmers should use crop reports as material to make their forecasts, and that information should not be sorted by the USDA. He argued that even though the problem was complex, farmers were able to compare today's data (either local, national, or world market conditions) with past data or averages (ibid.). ${ }^{10}$ Replying to Estabrook

\footnotetext{
${ }^{10}$ The simple rule was then the following: "If [the crop report indicates] more, prices are not likely to
} 
in the Journal of Farm Economics, Williams - a farmer-stockman — stated that "they get nothing out of past movements of prices unless they can be made to see the relationship between this past movement and future ones" (Williams 1929, p. 86). Moreover, according to him, the farmers knew what kind of information they wanted and agricultural economists should edit it as requested.

On top of discussions about the collection of information, editing was subject to arguments that in the end reflected different conceptions of expertise. Another important and related issue that faced agricultural economists was the means of diffusing the information.

\section{Diffusing information countrywide: The example of the market news service}

The editing of information depended crucially on the technological support through which it was diffused. In the early $20^{\text {th }}$ century, news might take days to reach the more isolated parts of the country. In the 1910s, the USDA already mailed bulletins to inform farmers about weather, marketing, and management. However, these bulletins were long to produce and they had difficulty reaching the farmers. Even when they did, the USDA acknowledged that the interpretation and application of the information was hard (USDA 1915, pp. 32-34). Hence, it was necessary to improve the diffusion of information.

The USDA used a variety of means to diffuse information. They worked with the extension services of experimental stations established by the Smith Lever Act (1914). One of the goals of the extension services was to aid in "diffusing among the people of the United States useful and practical information [...] in cooperation with the United States Department of Agriculture" (United States 2017, §341). The issue of diffusing market information existed before the arrival of economists in the USDA. In 1914, the Bureau of the Secretary established an "Office of Information", primarily to facilitate the diffusion of USDA information to newspapers. In the following year, the market news service was 
established by the Bureau of Markets (USDA 1915, p. 30).

In order to serve the war effort, the market news service aimed to build a national network to diffuse information quickly countrywide. The service was composed of a central office in Washington and local offices, also called "market stations". The market stations managed the collection and diffusion of information at a local level. After the war, it had more than 30 permanent local offices (USDA 1919), but suffered from budget constraints in the following years. However, from the mid-1920s, the BAE refunded the service, allowing it to reach 50 permanent local offices in the mid-1930s. The market news reports primarily focused on a few fruits and vegetables. In the 1930s, it eventually covered all the other agricultural products (BAE 1931, p. 5). The USDA also worked to collect and diffuse information on the agricultural conditions of other countries against which U.S. farmers might compete (USDA 1927, pp. 57-58). In the early 1930s, the USDA had offices in London, Berlin, Marseilles, Shanghai, Belgrade, Buenos Aires, Pretoria, and Sydney.

The market news service used several means to diffuse information to farmers. USDA reports were sent to local offices and then mailed to the market participants. Economists mostly used newspapers, which remain over the period the medium with the largest audience. In particular, the USDA wrote daily or weekly columns to be published in newspapers willing to diffuse them. The market news service also provided the "Agriogram", a radio broadcast. The BAE telegraphed ready-to-use reports to be broadcast by local offices and other partners such as chambers of commerce, private radios, state colleges' extension services, and college radios (ibid., p. 625). In the early 1920s, the radio network was mostly established in the North and East of the country. Other regions (e.g., Nebraska, Kansas, South Dakota, Iowa, Oklahoma) were too distant with regard to the existing telegraph and radio network at the time. In the following years, the radio network expanded to central and western regions. The USDA claimed in 1926 that they broadcast their reports on more than 80 radio stations (ibid., p. 624). The USDA also advocated the use of radio in farms. The results of their surveys showed an estimate of 145,000 radio sets on farms in 1923, 365,000 in 1924, and more than 553,000 in 1925. 
It has already been noted that the USDA was an enthusiastic supporter of new communication technologies (Wik 1988, Craig 2001). The regular changes in market conditions, and especially in prices, pushed the BAE to acknowledge the relevance of diffusing these changes promptly. For USDA's agricultural economists, the radio was viewed as the best means for diffusing information because it enabled the department to communicate $d i$ rectly with the farmers, i.e., without intermediaries. In 1923, W. A. Wheeler, in charge of the Market News Service of the USDA, promoted radio as "the only means of giving [farmers] quickly and at small cost the economic information necessary in the proper conduct of the farm business." (Wheeler 1923, 214, see figure 1).
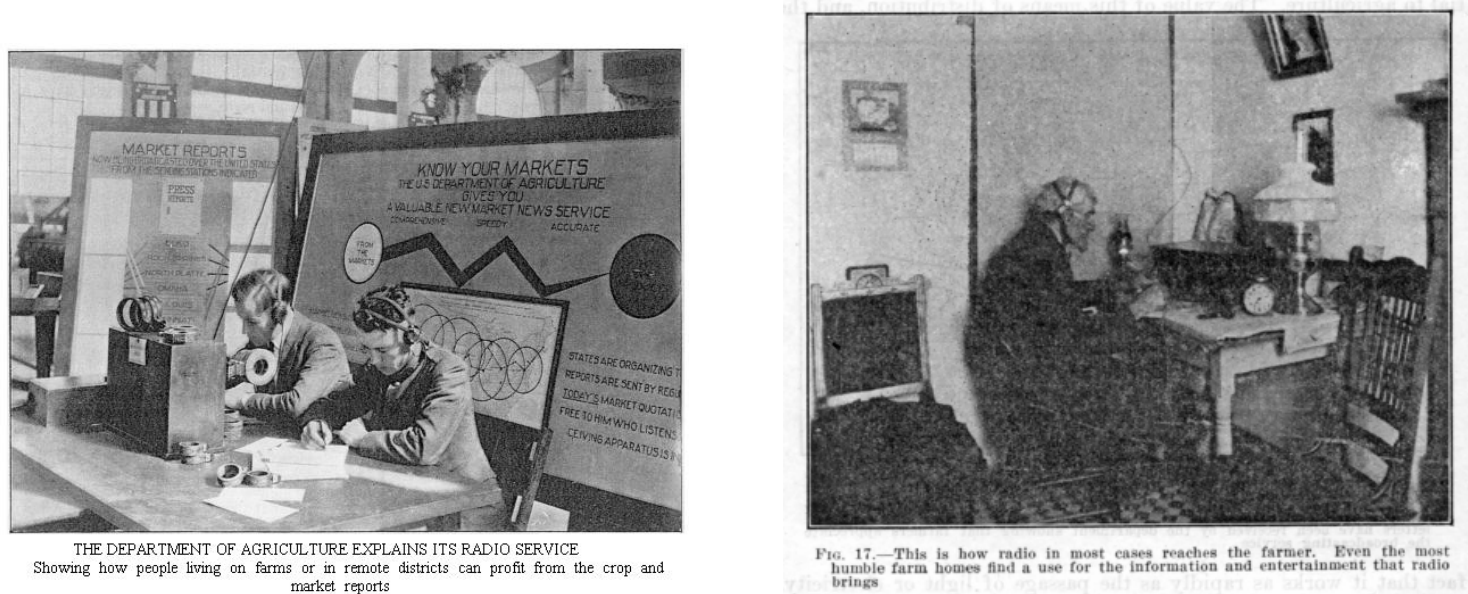

Figure 1: Radio Broadcast, 1922, p. 186

If BAE's economists primarily worked for the benefit of farmers, they also served other market participants such as trading agencies (e.g. BAE 1926, p. 39; BAE 1928, p. 53). Through market news services and the others means of diffusing information, economists viewed the BAE as the producer and distributor of accurate information on the agricultural economy to all parties. Chief economists of the BAE repeatedly emphasized the "unbiased" nature of the information they provided (BAE 1925, p. 3; BAE 1926 , p. 27; BAE 1933 , p. 13). One of the more explicit advocates of BAE's informational role was the economist Nils Olsen, chief of the BAE between 1928 and 1935. He viewed the market news service as an "unbiased, impartial, accurate source of information", the "eyes and ears of the agricultural markets", providing "facts in a world of rumors" (BAE 1933, p. 13). Olsen did not hesitate to claim that farmers, thanks to the radio, were 
"better advised than many individuals actually trading on the market" (BAE 1934, p. 7) or that the market news service was comparable in "speed and precision [...] to that supplied by the ticker service in the financial world" (BAE 1933, p. 13).11

Inside the USDA, the GFA was the only administration interested in financial activities, and it was through this institution that the discussion about information became theoretical.

\section{Making things theoretical: The debates between the GFA and Working .}

Following the USDA's agenda, it was clear for the GFA that improving the efficiency of futures markets depended mainly on improving the accuracy of information circulating in markets. In a retrospective work celebrating the 15th anniversary of the GFA, two of its economists ${ }^{12}$ influenced by Paul Melh - an agricultural economist recruited in 1924 at GFA's Chicago office stated that:

A perfectly informed market is one in which all the participants are armed with full knowledge of past and current trade conditions. A perfectly competitive market is one entirely free from control of any sort. It is not difficult to argue that present-day markets are far from this ideal. (Hoffman and Duvel 1941, p. 70)

From its early years, the GFA warned about the danger of spurious information disseminated in markets through private telegraph services (GFA 1924, p. 3). For them, traders were mostly misinformed. The GFA thought that the excessive speculation from small but numerous ill-informed traders was one of the greatest threats to the stability of futures markets (Berdell and Choi 2018, p. 543). From the GFA's standpoint, the limitation of futures trading volumes was the best way to reduce price volatility. The different reports

\footnotetext{
${ }^{11}$ See Preda $(2006)$ for a historical account of the introduction of the ticker service.

${ }^{12}$ Joseph W. T. Duvel, chief of the GFA, wrote most of its reports with George W. Hoffman, an economist consultant of the GFA, who was also Professor of Insurance at the Wharton School. However, according to Berdell and Choi (2018, p. 543), GFA's views were mainly
} 
in the 1920s and the 1930s systematically suggested limiting futures trading (e.g. Duvel and Hoffman 1928). In 1936, the Commodity Exchange Act reinforced GFA's power and imposed limits on open positions and daily trading (Berdell and Choi 2018, p. 551).

Contrary to the BAE, the GFA's interest in information also led to theoretical debates, notably about the degree of informedness of traders and its consequence on price behavior. Indeed, the GFA aimed not only to prevent the circulation of misleading information, but also to measure its effect on futures prices. GFA's economists discussed these issues in economic articles published in the Journal of Farm Economics (Mehl 1934; Hoffman 1937; Mehl 1940). They remained convinced that futures prices departed from fundamentals and that futures traders remained mostly ill-informed. A session on futures markets during the 1936 annual conference of the American Farm Economic Association discussed the capacity of futures prices to forecast future conditions. George Hoffman, an economist from the GFA, argued that past economists gave too much credit to the ability of futures traders to "display a superior knowledge" (Hoffman 1937, p. 308). Traders were poorly informed, and futures price fluctuations remained "a very random and uncertain affair" (ibid.).

GFA's view of speculation driven by unsophisticated gamblers was not entirely accepted among agricultural economists interested in futures trading.13 Probably the most important figure to support an opposing stance was Holbrook Working. Working (18951985) wrote a PhD in Agricultural Economics in 1921 at the University of Wisconsin, one of the strongholds of American institutionalism. He then taught at Cornell University and the University of Minnesota before joining the Food Research Institute (FRI) at the University of Stanford, where he remained until his retirement. The FRI had been established thanks to the strong support of Herbert Hoover (Secretary of Commerce between 1921 and 1928 and 31 ${ }^{\text {st }}$ U.S. President between 1929 and 1933).14 The FRI was a rare example of a private institution conducting agricultural economic research (the Social Science Research Council funded by the Rockefeller Foundation was another example).

\footnotetext{
${ }^{13}$ Even within the GFA, see in particular Berdell and Choi (2018, p. 553).

${ }^{14}$ Hoover strongly promoted the use of statistics and economics in conducting policies on commerce and agriculture; see Barber (1989)
} 
Although he was employed outside the GFA, Working was a regular consultant and commentator of their research. Working was in the room during Hoffman's presentation at the 1936 Annual Conference, and, although he agreed on the importance of information for futures trading, he suggested that:

$[\mathrm{P}]$ rices, as they are determined in modern speculative markets are not so haphazard and imperfect as one may judge from too restricted a view of the information and trading habit of individual speculators. (Working 1937 , p. 310)

Already in 1922, Working had suggested that traders must be well-informed to find arbitrage opportunities. This was the case for geographical arbitrage-i.e., across local markets - as well as time arbitrage -i.e., between present and future prices (Working 1922 , p. 6).

Working did not consider that this view was antagonistic with the work of the USDA and the GFA, with whom he had a close working relationship (Berdell and Choi 2018). He repeatedly suggested that market participants were better informed than his colleagues claimed. However, this remained an intuition for which he acknowledged a lack of empirical evidence. As he recalled in a letter to Paul Samuelson, ${ }^{15}$ he and the FRI had supported this view since the 1930s without having "possibilities for objective testing of the validity of our impressions.'16

While Working's theoretical contributions came later, the influence of the USDA's program was already visible in his earlier works. In one of his first articles, Working already acknowledged the role of BAE's market news service in informing market participants. Moreover, he suggested that USDA reforms had reduced the price gap for agricultural commodities between different local markets:

The market news service of the United States Department of Agriculture has done much to make it easy for dealers to keep informed regarding prices

\footnotetext{
${ }^{15}$ Samuelson had been a prominent contributor to the research program on the efficient market hypothesis in the 1960s (Samuelson 1965) and was in touch with Working in the early 1960s (Delcey 2019).

${ }^{16}$ Letter to Samuelson, May 2, 1961. Samuelson's manuscripts, Rubinstein Library, Duke University.
} 
and supplies in other markets [...] The result is that prices in all the markets of the country are very closely related. (Working 1922 , p. 6)

In the late 1940s, ${ }^{17}$ Working found a solution by linking his view on information with the difficulty to forecast prices changes - and thus formulated an early version of the efficient market hypothesis. The difficulty to forecast price changes had already been acknowledged by U.S. scholars from at least the 1920s, and notably by NBER scholars (MacCauley 1925, King 1930), by Working himself (Working 1934), and by Alfred Cowles (Cowles 1933: Cowles and Jones 1937; Cowles 1944). While these works raised doubts about the forecasting skills of speculators, Working (1949a) explicitly recommended a reinterpretation of these results. He argued that, in an "ideal market", speculators' expectations "would have taken full account of the information which permitted the successful prediction of the price" (ibid. p. 160). Thus, "apparent imperfection of professional forecasting, therefore, may be evidence of perfection of the market. The failures of stock market forecasters, to which we referred earlier, reflect credit on the market" ibid., p. 159). From the 1950s onward, Working began to bring these ideas together in a single theoretical framework. Working viewed futures markets as an institution disseminating the dispersed and private information of individual traders. Futures traders, guided by the search for arbitrage opportunities, are "forced and induced to engage in a sort of informal division of labor in their use of available information" (Working 1958, p. 194). Empirically, such behavior should lead to frequent and unpredictable price changes.

In contrast to GFA's views, Working considered the market as an efficient institution for the disclosure of continuously scattered information to market participants. Despite his disagreement with GFA's economists, Working had a deep respect for their pioneering research on the functioning of futures trading. In one of his last publications, reflecting on the research of the last few decades on futures markets, Working paid tribute to the data collection work that the GFA had carried out. He notably praised Duvel, the chief of the GFA, who "gave research a prominent place in the work of that regulatory body"

\footnotetext{
${ }^{17}$ In the 1940s, most of Working's works $(1942,1948,1949 \mathrm{~b}, 1953)$ did not directly discuss the issue of information. During this period, he notably developed his famous concept of "price of storage" (Working 1949b). A presentation of his theory can be found in Working (1953).
} 
(Working 1962, p. 434).

\section{Concluding remarks}

While Working and GFA's economists disagreed on the accuracy of traders' information, they shared the view that information was central to the determination of futures prices. Although the legacy of GFA's analysis to economic analysis has already been noted (Saleuddin 2018; Berdell and Choi 2018), we show that investigating the broader interest that USDA's economists had for information brings new insights to the history of economic analysis. Disagreements between Working and USDA's economists on the accuracy of market participants' information also emphasize the common belief that information was essential for the functioning of markets.

It is also interesting to note that this common belief was firstly embodied in policyoriented rather than academic contributions. The development of a theory of information was the last chapter in the story. Early economic policies led to a research program aiming to collect and disseminate information. Then, some agricultural economists formulated analytical arguments about the accuracy of market participants' information, and suggested an empirical relation to price volatility. GFA's and Working's contrasted stances can only be appreciated thanks to the prior efforts of USDA's economists to collect and distribute market information.

\section{References}

Alonzo, A. (2017). 100 Years of USDA Market News: The Trusted Source - Then, Now and Always. U.S. Department of Agriculture. URL: https://www.usda.gov/media/ blog/2015/02/11/100-years-usda-market-news-trusted-source-then-nowand-always (visited on 06/08/2020).

BAE (1924). Report of the Chief of the Bureau of Agricultural Economics. Washington, D.C.: Office of Government Printing. 
- (1925). Report of the Chief of the Bureau of Agricultural Economics. Washington, D.C.: Office of Government Printing.

BAE (1926). Report of the Chief of the Bureau of Agricultural Economics. Washington, D.C.: Office of Government Printing.

- (1928). Report of the Chief of the Bureau of Agricultural Economics. Washington, D.C.: Office of Government Printing.

- (1931). Report of the Chief of the Bureau of Agricultural Economics. Washington, D.C.: Office of Government Printing.

- (1933). Report of the Chief of the Bureau of Agricultural Economics. Washington, D.C.: Office of Government Printing.

- (1934). Report of the Chief of the Bureau of Agricultural Economics. Washington, D.C.: Office of Government Printing.

Barber, W. J. (1989). From New Era to New Deal: Herbert Hoover, the Economists, and American Economic Policy, 1921-1933. Reprint edition. Cambridge: Cambridge University Press. 252 pp.

Berdell, J. and J. W. Choi (2018). "Clashing Analyses of Speculation and the Early Regulation of US Futures Markets". In: Journal of the History of Economic Thought 40.4, pp. 539-560.

Biddle, J. (1999). "Statistical Economics, 1900-1950". In: History of Political Economy 31.4, pp. 607-651.

Call, L. E., R. M. Green, and C. O. Swanson (1925). "How To Grow and Market HighProtein Wheat". In: ed. by Agricultural Experiment Station, Kansas State Agricultural College, Departments of Agronomy, Agricultural Economics and Milling Industry. Circular 114.

Carpenter, D. (2001). The Forging of Bureaucratic Autonomy: Reputations, Networks, and Policy Innovation in Executive Agencies, 1862-1928. Princeton Studies in American Politics: Historical, International, and Comparative Perspectives. Princeton University Press. 
Chancellier, E. (2014). "Les Débuts Du Bureau of Agricultural Economics - La Modélisation Des Récoltes (1922-1930)". In: Histoires 8 Sociétés Rurales 42.2, pp. 113147.

Cooper, T. (1929). "[Encouraging the Farmer to Take Agricultural Outlook Material and Use It]: Discussion". In: Journal of Farm Economics 11.1, pp. 125-127.

Cowles, A. (1933). "Can Stock Market Forecasters Forecasts". In: Econometrica 1, pp. 309324.

— (1944). "Stock Market Forecasting". In: Econometrica 12.3/4, pp. 206-214.

Cowles, A. and H. Jones (1937). "Some a Posteriori Probabilities in Stock Market Action". In: Econometrica 5, pp. 289-294.

Craig, S. (2001). "'The Farmer's Friend": Radio Comes to Rural America, 19201927”. In: Journal of Radio Studies 8.2, pp. 330-346.

Delcey, T. (2019). "Samuelson vs Fama on the Efficient Market Hypothesis: The Point of View of Expertise". In: Oeconomia. History, Methodology, Philosophy 9-1 (9-1), pp. $37-58$.

Didier, E. (2009). En Quoi Consiste l'Amérique? Collection Anthropologie Des Sciences et Des Techniques". Paris: La Découverte. 320 pp.

Duvel, J. W. T. and G. W. Hoffman (1928). Major Transactions in the 1926 December Wheat Future. Technical Bulletin 79. Washington, D.C.: United States Department of Agriculture.

Elliott, F. (1929). "Experimental Method in Economic Research". In: Journal of Farm Ecconomics 11.4, pp. 594-596.

Estabrook, L. M. (1923). "The Use of Crop Reports by Farmers". In: Journal of Farm Economics 5.1, pp. 28-35.

Fisher, R. A. (1925). Statistical Methods for Research Workers. Edinburgh: Oliver and Boyd. 239 pp.

Fite, G. C. (1971). "The Reluctant Farmer: The Rise of Agricultural Extension to 1914. By Roy V. Scott. Urbana, III., University of Illinois Press, 1970. Pp. Xi + 362. \$8.95.” In: Business History Review 45.4, pp. 530-531. 
Fox, K. A. (1986). "Agricultural Economists as World Leaders in Applied Econometrics, 1917-33". In: American Journal of Agricultural Economics 68.2, pp. 381-386.

GFA (1924). Report of the Chief of the Grain Futures Administration 1923. Washington, D.C.: Office of Government Printing.

Grimes, W. E. (1929). "Experimental Method in Economic Research". In: Journal of Farm Economics 11.4, pp. 584-586.

Harding, T. S. (1947). Two Blades of Grass. A History of Scientific Development in the U.S. Department of Agriculture. Norman: University of Oklahoma Press.

Hart, V. (1929). "Encouraging the Farmer to Take Agricultural Outlook Material and Use It". In: Journal of Farm Economics 11.1, pp. 108-125.

Hoffman, G. W. (1937). "Past and Present Theory Regarding Futures Trading". In: Journal of Farm Economics 19.1, pp. 300-309.

Hoffman, G. W. and J. W. T. Duvel (1941). Grain Prices and the Futures Market: A 15Year Survey, 1923-1938. Technical Bulletin. United States Department of Agricutlure. Jovanovic, F. (2008). "The Construction of the Canonical History of Financial Economics". In: History of Political Economy 40.2, pp. 213-242.

King, W. I. (1930). Index Numbers Elucidated. Longmans Economic Series. New York, London: Longmans, Green and co. 226 pp.

Kirkendall, R. S. (1966). Social Scientists and Farm Politics in the Age of Roosevelt. Columbia: University of Missouri Press. 358 pp.

Lenfant, J.-S. (2017). "Early Debates on Quality, Market Coordination and Welfare in the U.S. in the 1930s".

Lininger, F. F. (1929). "Market Information and the Farmer's Problems". In: The Annals of the American Academy of Political and Social Science 142, pp. 341-351.

MacCauley, F. R. (1925). "Forecasting Security Prices". In: Journal of the American Statistical Association 20.150, pp. 244-249.

McDean, H. C. (1983). "Professionalism in the Rural Social Sciences, 1896-1919". In: Agricultural History 57.1, pp. 64-82. 
- (1984). "Professionalism, Policy, and Farm Economists in the Early Bureau of Agricultural Economics". In: Agricultural History 58.3, pp. 373-392.

Mehl, P. (1934). "Trading in Futures and Price Fluctuations". In: Journal of Farm Economics 16.3, pp. 481-495.

- (1940). "Trading in Wheat and Corn Futures in Relation to Price Movements". In: Journal of Farm Economics 22.3, pp. 601-612.

Mehrling, P. (1997). The Money Interest and the Public Interest: American Monetary Thought, 1920-1970. Cambridge, MA: Harvard University Press. 288 pp.

Mirowski, P. (1987). "The Philosophical Bases of Institutionalist Economics". In: Journal of Economic Issues 21.3, pp. 1001-1038.

Mirowski, P. and E. Nik-Khah (2017). The Knowledge We Have Lost in Information: The History of Information in Modern Economics. Oxford, New York: Oxford University Press. 312 pp.

Morgan (1991). The History of Econometric Ideas. Cambridge: Cambridge University Press. 316 pp.

National Archives (1995). "Records of the Bureau of Agricultural Economics [BAE] Web Version Based on Guide to Federal Records in the National Archives". In: ed. by R. B. M. et al.

Preda, A. (2004). "Informative Prices, Rational Investors: The Emergence of the Random Walk Hypothesis and the Nineteenth-Century Science of Financial Investments". In: History of Political Economy 36.2, pp. 351-386.

- (2006). "Socio-Technical Agency in Financial Markets: The Case of the Stock Ticker". In: Social Studies of Science 36.5, pp. 753-782.

Rutherford, M. (2001). "Institutional Economics: Then and Now". In: Journal of Economic Perspectives 15.3, pp. 173-194.

- (2011). "The USDA Graduate School: Government Training in Statistics and Economics, 19211945". In: Journal of the History of Economic Thought 33.4, pp. 419447. 
Saleuddin, R. (2018). The Government of Markets: How Interwar Collaborations between the CBOT and the State Created Modern Futures Trading. Palgrave Studies in the History of Finance. Palgrave Macmillan.

Samuelson, P. A. (1965). "Proof That Properly Anticipated Prices Fluctuate Randomly". In: Industrial Management Review 6.2, pp. 41-49.

Santos, J. (2008). A History of Futures Trading in the United States. Ed. by R. Whaples. Economic History Association.

Scott, R. V. (1971). The Reluctant Farmer: The Rise of Agricultural Extension to 1914. Urbana: University of Illinois Press. 362 pp.

Stapleford, T. A. (2017). "Business and the Making of American Econometrics, 19101940". In: History of Political Economy 49.2, pp. 233-265.

Taylor, H. C. (1940). "Early History of Agricultural Economics". In: Journal of Farm Economics 22.1, pp. 84-97.

United States (2017). "U.S. Code, Title 7 - Agriculture, Chapter 13 - Agricultural and Mechanical Colleges, Subchapter IV - Agricultural Work Appropriation”. In: ed. by Cornell Law School.

USDA (1907). Yearbook of the United States Department of Agriculture 1906. In collab. with USDA. Washington, D.C.: Office of Government Printing.

- (1914). Yearbook of the United States Department of Agriculture 1913. Washington, D.C.: Office of Government Printing. 597 pp.

- (1915). Yearbook of the United States Department of Agriculture 1914. Washington, D.C.: Office of Government Printing. 769 pp.

- (1919). Yearbook of the United States Department of Agriculture 1918. Washington, D.C.: Office of Government Printing. 823 pp.

- (1923). Yearbook of Agriculture 1922. Washington, D.C.: Office of Government Printing. $1145 \mathrm{pp}$.

- (1926). Yearbook of Agriculture 1925. Washington, D.C.: Office of Government Printing. 1544 pp. 
- (1927). Yearbook of Agriculture 1926. Washington, D.C.: Office of Government Printing. $1572 \mathrm{pp}$.

- (1930). "Classified List of Projets of the Agricultural Experiment Stations - Compiled in the Office of Experiment Stations". In:

USDA (1923/24-1934/35). Report of Chief of Bureau of Agricultural Economics. Washington, D.C.: Government Printing Office.

Warren, G. F. (1932). "The Origin and Development of Farm Economics in the United States". In: Journal of Farm Economics 14.1, p. 2.

Wheeler, W. A. (1923). "Down on the Farm in 1923". In: Radio Broadcast, pp. 212-214.

Wik, R. M. (1988). "The USDA and the Development of Radio in Rural America". In: Agricultural History 62.2, pp. 177-188.

Williams, C. (1929). "Continuous Economic Information Readily Available to Farmers". In: Journal of Farm Economics 11.1, pp. 79-94.

Wilson, M. L. (1929). "Experimental Method in Economic Research". In: Journal of Farm Economics 11.4, pp. 578-583.

Working, H. (1922). Factors Determining the Price of Potatoes in St. Paul and Minneapolis. Technical Bulletin 7528. University of Minnesota, Agricultural Experiment Station.

- (1934). "A Random-Difference Series for Use in the Analysis of Time Series". In: Journal of the American Statistical Association 29.185, pp. 11-24.

- (1937). "Futures Trading and Regulations: Discussion by Holbrook Working". In: American Journal of Agricultural Economics 19.1, pp. 309-312.

- (1949a). "The Investigation of Economic Expectations". In: American Economic Review 39.3, pp. 150-166.

- (1949b). "The Theory of Price of Storage". In: American Economic Review 39.6, pp. $1254-1262$.

— (1953). "Futures Trading and Hedging". In: American Economic Review 43.3, pp. 314343. 
- (1958). "A Theory of Anticipatory Prices". In: American Economic Review 48.2, pp. 188-199.

- (1962). "New Concepts Concerning Futures Markets and Prices". In: American Economic Review 52.3, pp. 431-459. 